\title{
Surgical Skills Beyond Scientific Management
}

\author{
NICHOLAS WHITFIELD* \\ Department of Social Studies of Medicine, McGill University, 3647 Peel Street, \\ Montreal H3A 1X1, Canada
}

\begin{abstract}
During the Great War, the French surgeon Alexis Carrel, in collaboration with the English chemist Henry Dakin, devised an antiseptic treatment for infected wounds. This paper focuses on Carrel's attempt to standardise knowledge of infected wounds and their treatment, and looks closely at the vision of surgical skill he espoused and its difference from those associated with the doctrines of scientific management. Examining contemporary claims that the Carrel-Dakin method increased rather than diminished demands on surgical work, this paper further shows how debates about antiseptic wound treatment opened up a critical space for considering the nature of skill as a vital dynamic in surgical innovation and practice.
\end{abstract}

Keywords: Surgery, Antisepsis, Scientific management, Standardisation, Deskilling, The First World War

\section{Introduction}

Speaking at the sixty-fifth annual session of the American Medical Association in 1914, the renowned surgeon of the Johns Hopkins Hospital, John Finney, remarked on the desirable qualities of the surgical practitioner in a climate of professional change. 'Among the requisites necessary for a surgeon', he declared, 'is a certain saneness of mind, better understood than described. While now and then some erratic genius will, meteor-like, appear on the surgical horizon, a closer analysis will usually show that like the celestial visitor he shines with great brilliancy for a moment, but leaves behind him little that is tangible or lasting.'

Finney's topic was the 'standardization of the surgeon', and his aim to convince a troubled audience of the need to embrace currents of change visible more broadly across American medicine of the early-twentieth century, lest such standards be imposed arbitrarily upon them to the disadvantage and possible devastation of their inscrutable craft. Fortunately for Finney, surgeons of the celestial kind were rare exceptions to a terrestrial norm, and solutions to the problem of standardisation were various. Here I

\footnotetext{
* Email address for correspondence: nicholas.whitfield@mail.mcgill.ca

I thank Thomas Schlich and the participants of the 2012 'History of Skill in Medicine and Science' workshop at McGill University for commenting on an earlier version of this paper, and for helpful discussions about the history of surgical skills. I am also grateful to staff at the Rockefeller Archive Center in New York, the editors of Medical History, and to three anonymous referees who provided detailed constructive criticism.
}

1 J.M.T. Finney, 'The Standardization of the Surgeon', Journal of the American Medical Association, 63, 17 1433-7 (24 October, 1914), 1434. 
consider one attempt to standardise a therapeutic innovation during the First World War (1914-18), the Carrel-Dakin antiseptic treatment for infected wounds. The focus is on its principal innovator, Alexis Carrel, the Nobel prize-winning surgeon and self-defined disciple of science, and his novel approach to the question of standardisation. Wary of his celestial status among a surgical profession of sharply varying abilities, Carrel faced the problem of promoting a difficult technique in unfavourable conditions. In doing so, he espoused a vision of surgical skill that emphasised broad experience, attention to detail and spectatorship in education. He sought not to corrode or devalue surgical skills but to enjoin surgeons to the scientific principles of antisepsis in order to improve its practice on the front lines.

Such an interpretation of Carrel's efforts can appear strange alongside much existing historiographical work on developments in scientific medicine during the years just prior to the First World War. For at least three decades, historians have contended that medical disciplines of the period both imported and contributed to a maelstrom of wider changes, loosely connected to themes of efficiency, rationalisation, economy and 'scientific management'. Ranging from the traffic of organic and industrial metaphors between physiology and industry to the importation of cost accounting by medical institutions, scholars have arrayed rich and varied evidence in support of the mutuality of medical practice on the one hand, and strategies developing in business and engineering on the other. ${ }^{2}$ Standardisation was but one element in a much wider spectrum of changes associated with the longer rise of scientific medicine. ${ }^{3}$ Historians have paid special attention to the influence of Frederick Winslow Taylor's famous theories of scientific management, a conscious response to the perceived inefficiency of late-nineteenth century American labour, ${ }^{4}$ noting how scientific medicine in America and Europe exemplified a comparable will to control and standardise practitioners and patients, turning the tools of science against the varied ills of modern life. By confronting a historiographical tradition that both presumed and imposed artificial divisions between medicine-in-particular and society-at-large, this scholarship has made a powerful case that medicine and science have been as much part of broader historical forces as their passive recipients, not divorced from but thoroughly entwined with the varied dynamics and pressures of their shifting historical scenes. 5

2 Joel Howell, Technology in the Hospital: Transforming Patient Care in the Early Twentieth Century (London: The Johns Hopkins University Press, 1995), 30-68; Susan Reverby, 'Stealing the Golden Eggs: Ernest Amory Codman and the Science and Management of Medicine', Bulletin of the History of Medicine, 55 (1981), 156-71; George Rosen, 'The Efficiency Criterion in Medical Care, 1900-20: An Early Approach to an Evaluation of Health Service', Bulletin of the History of Medicine, 50 (1976), 28-44; Thomas Schlich, 'The Art and Science of Surgery: Innovation and Concepts of Medical Practice in Operative Fracture Care, 1960s-70s', Science, Technology, \& Human Values, 32, 1 (2007), 65-87; idem, 'The Perfect Machine: Lorez Bohler's Rationalized Fracture Treatment in World War I', Isis, 100, 4 (2009), 758-91; Daniel P. Todes, 'Pavlov's Physiology Factory', Isis, 88, 2 (2002), 205-46.

${ }^{3}$ Rosemary Stevens, In Sickness and in Wealth: American Hospitals in the Twentieth Century (New York: Basic Books, 1989), 90; Harry Marks, The Progress of Experiment: Science and Therapeutic Reform in the United States, 1900-90 (Cambridge: Cambridge University Press, 1997), 1-14. On the historical relations of science and surgery after the Second World War, see Thomas Schlich, Surgery, Science and Industry: A Revolution in Fracture Care, 1950s-90s (Basingstoke: Palgrave Macmillan, 2002).

${ }^{4}$ Samuel Haber, Efficiency and Uplift: Scientific Management in the Progressive Era 1890-1920 (Chicago: University of Chicago Press, 1964); Howell, op. cit. (note 2), 30.

${ }^{5}$ Roger Cooter, Surgery and Society in Peace and War: Orthopaedics and the Organization of Modern Medicine, 1880-1948 (Macmillan Press: London, 1993); Roger Cooter and Steve Sturdy, 'Science, Scientific Management, and the Transformation of Medicine in Britain, c.1870-1950', History of Science, 36, 4 (1998), 422-66. A recent exploration of countercurrents in medicine to the aesthetics of modernism is John Harley Warner, 'The Fielding 
Yet raising such parallels presents its own risks. It can, for example, obscure divergences between the realms of scientific medicine and management (of the sort considered here), and can reproduce assumptions about the forces of standardisation in medical practice. One such assumption, common to attacks made on the managerial philosophies of Taylor and his followers, is that standardisation leads inherently to a general deskilling of work, or to the devaluation of clinical skills. ${ }^{6}$ Claims about deskilling typically present 'skill' as a stable and self-evident category. In contrast, this paper foregrounds the historical contingency and mutability of skill as a concept, the shifting definitions of which were implicated in the history of surgery and surgical innovations during the Great War, as well as in the growing frontier of scientific management. Claims of deskilling stand in opposition to the contemporary view that the Carrel-Dakin method was skill demanding: admirers and detractors alike maintained that it presupposed lavish facilities and highlytrained practitioners; their discussions reveal a conceptual preoccupation with skill as a driving force in surgical innovation.

The aim here is to supplement rather than to contradict the insights of earlier historiography, and to stress variations among the broader processes it describes. Like the multiple meanings of science in medicine, the scientific management of medicine proceeded along various routes - as did the pursuit of standardisation. ${ }^{7}$ Undeniably, Alexis Carrel's science of wounds bore much synthetic resemblance to Frederick Taylor's reform of management. As discussed in the first two sections of this essay, Carrel presented his innovation as thoroughly scientific, and drew simultaneously on the tools of engineering and experimentation to build his case for antisepsis. ${ }^{8}$ Like Taylor, he strove to standardise his routines across military and civil surgery, imploring colleagues to adopt his scientifically-founded method and to follow his instructions precisely. Yet differences abound in the sense of what skill comprised. The latter two sections attempt to clarify these differences. The third notes the (material and embodied) frustrations of achieving a standardised treatment of infected wounds, and the kinds of demands it placed on military surgeons. The fourth looks at Carrel's response to these difficulties, how he attempted to propagate the scientific principles of his wound treatment at a specially-appointed War Demonstration Hospital in New York City. This final section draws out the contrast between concepts of skill specific to the pedagogical practices of scientific management and those fathomed by Carrel, showing the latter to be rooted in older surgical traditions of spectatorship, apprenticeship, and direct demonstration. ${ }^{9}$

Garrison Lecture: The Aesthetic Grounding of Modern Medicine', Bulletin of the History of Medicine, 88, 1 (2014), 1-47.

${ }^{6}$ For example: Harry Braverman, Labor and Monopoly Capital: The Degradation of Work in the Twentieth Century (New York: Monthly Review Press, 1974); Desley Deacon, 'Taylorism in the Home: The Medical Profession, the Infant Welfare Movement and the Deskilling of Women', ANZJS, 21, 2 (1985), 161-73. On the claimed bad effects of technologies on medical skill, see Stanley J. Reiser, Medicine and the Reign of Technology (Cambridge: Cambridge University Press, 1978), 158-73, 196-226. Specific to the Carrel-Dakin method, see Perrin Selcer, 'Standardizing Wounds: Alexis Carrel and the scientific management of life in the First World War', British Journal for the History of Science, 41, 1 (2007), 73-107. Selcer's detailed account has been important for the present study, the point of difference being the notion of deskilling as an inherent feature of standardisation. For a critique of the deskilling thesis in labour history, see Paul Attewell, 'The Deskilling Controversy', Work and Occupations, 14, 3 (1987), 323-46, and literature cited in the introduction to this special issue.

7 John Harley Warner, 'Science in Medicine', Osiris, 2nd series, 1 (1985), 37-58: 50-4.

8 There is by now a large secondary literature on this method, the best of which is Selcer, op. cit. (note 6), 73-107. See also: Owen Wangensteen and Sarah Wangensteen, 'Military Surgeons and Surgery, Old and New: An Instructive Chapter in Management of Contaminated Wounds', Surgical History, 62, 6 (1967), 1102-24.

${ }^{9}$ On direct demonstration in surgery, see Sally Wilde and Geoffrey Hirst, 'Learning From Mistakes: Early Twentieth-Century Surgical Practice', Journal of the History of Medicine and Allied Sciences, 64, 1 (2008), 


\section{The Carrel-Dakin Method}

Late in 1916, the French surgeon and scientist Alexis Carrel received a congratulatory notice from the former President of the United States, Theodore Roosevelt, regarding his work on the treatment of infected wounds. Evident in Roosevelt's praise was much of the optimism and anxiety that underpinned the American predicament in the early decades of the twentieth century: the promise of medicine to the industrial priorities of a nation; progress equated brazenly with science; harmony among the interests of humanity and economy; efficiency and productivity; the dream of standardisation. ${ }^{10}$ 'Even a layman like myself', Roosevelt confided,

can see the immense value your discovery will have not only in military but in civil, especially industrial, surgery. If accepted in the army your new method of treatment will not only conserve life and limb, - which from the economic and military standpoint is of vital importance - but will also alleviate most of the pain and suffering of the wounded. I wish it were possible to standardize this method of treatment so as to give the wounded the best that science affords. ${ }^{11}$

This much was clear to Carrel. Never doubtful of his innovations' wider significance, by the time he won Roosevelt's praise he had already enjoyed an illustrious career. By 1912, the year he received the Nobel Prize in medicine and physiology for his contributions to vascular surgery, ${ }^{12}$ he embodied the celestial genius about which Finney would later be so derisive. ${ }^{13}$ The young Carrel had openly rejected the authority of his medical superiors in his hometown of Lyon, and was bluntly critical of the bureaucratic, hierarchical and antiscientific nature of French medicine he held responsible for stifling surgical innovation. ${ }^{14}$ In 1904, following the presentation of his work on blood vessel repair at a medical congress in Montreal, Carrel won several invitations to work in America. He left France that year for the Hull Physiology Laboratory at the University of Chicago, where he continued work on vascular surgery, then in 1906 he moved to New York to the newly-established Rockefeller Institute for Medical Research. Just four years old, the institute was a citadel for the 'ideal of clinical medicine as a science', ${ }^{15}$ and therefore a perfect destination for Carrel, who by this time had shored up divisions between clinic and laboratory, and chosen sides. 'I hate medical practice', he conceded in 1906 to the neurosurgeon Harvey Cushing: 'I would

38-77; Andrew Warwick, 'X-rays as Evidence in German Orthopaedic Surgery, 1895-1900', Isis, 96, 1 (2005), 1-24: 22; Dawn Woodgate, 'Taking Things Apart: Ovario-Hysterectomy: Textbook Knowledge and Actual Practice in Veterinary Surgery', Social Studies of Science, (2006), 367-97.

${ }^{10}$ Edward T. Morman, 'Introduction', in Edward T. Morman (ed.) Efficiency, Scientific Management, and Hospital Standardization: An Anthology of Sources (London: Garland Publishing Inc., 1989), i-xxvii.

${ }^{11}$ Theodore Roosevelt to Alexis Carrel, 29 November 1916, Rockefeller Archive Center, Sleepy Hollow, NY (RAC), Rockefeller University (RU), Record Group (RG) I, Series 600-2, Box 15, Folder 7.

12 Thomas Schlich, The Origins of Organ Transplantation: Surgery and Laboratory Science, 1880-1930 (New York: University of Rochester Press, 2010), 185; for details of Carrel's suturing technique, see Owen Wangensteen and Sarah Wangensteen, The Rise of Surgery: From Empiric Craft to Scientific Discipline (Minneapolis: University of Minnesota Press, 1978), 264-5; see also Shelley McKellar, 'Innovation in modern surgery: Alexis Carrel and blood vessel repair', in Darwin H. Stapleton (ed.) Creating a Tradition of Biomedical Research: Contributions to the History of The Rockefeller University (New York: The Rockefeller University Press, 2004), 135-50, 137.

13 J.A. Witowski, 'Alexis Carrel and the Mysticism of Tissue Culture', Medical History, 23 (1979), 279-96.

${ }^{14}$ As a junior intern in Lyon, Carrel had been openly critical of the failure to save the life of Sudi Carnot, former President of the French Republic, who was assassinated in 1894 by a stab wound to the abdomen. Robert Cusimano, Michael Cusimano and Steven Cusimano, 'The genius of Alexis Carrel', Canadian Medical Association Journal, 131 (1984), 1142-50: 1142-4.

${ }^{15}$ Olga Amsterdamska, 'Research at the Hospital of the Rockefeller Institute for Medical Research', in Stapleton, Creating a Tradition of Biomedical Research (2004), 111-26. 
like better to make little money in doing scientific work than a great deal in doing surgical operations'. ${ }^{16}$ The institute gave him access to unparalleled facilities, and its director, Simon Flexner, allowed Carrel complete autonomy in the organisation of his workspace and choice of research, which over the next three decades spanned vascular surgery, organ transplantation and replantation, the study of wounds, techniques of tissue culture, ${ }^{17}$ and, towards the end of his career, social and political theory. ${ }^{18}$ Carrel honed an infamous style, donning dark overalls in surgical theatres rendered utterly in black (the reason he gave was to reduce the sun's glare; the rooms were lit by natural light), and exercising fastidious control upon his various assistants. ${ }^{19}$ Following his death in 1944, and partly due to the fascistic political beliefs he conveyed in his 1935 book Man the Unknown, his memory and reputation dimmed (as in Finney's prediction) to the extent that a generation of celebratory biographers now lament the faded legacy of a surgical genius and hero. ${ }^{20}$

At the outbreak of war in Europe in 1914, Carrel had volunteered for the French Medical Corps as aide-major whilst holidaying in France. In December that year he spent several days on the front, where he was impressed by the spirit of the French fighters, disillusioned by a chance encounter with Madame Curie ('a most conceited and ugly old woman' ${ }^{21}$ ), and regretful about the formidable problems of military surgery. 'I can not write what I saw in the hospitals', he confessed to Flexner, with whom he maintained regular contact: 'It is the failure of Medicine. ${ }^{22}$ Most unsettling for Carrel was the inadequate treatment of war wounds, which led to 'the frequent occurrence of gangrene, suppuration, and infections of all kinds' among the injured men. He noted with regret that '[m]edical and surgical science then has done very little ... for the treatment of the infected wounds of war'.$^{23}$ The failure of therapeutics was not based on ignorance about causation, however - bacteriologists had determined quickly that such wounds were the product of modern agriculture, French soils heavily cultivated with manure whose mingled debris penetrated deep into the clothing and torn flesh of combatant soldiers. ${ }^{24}$ In 1917, an American journalist offered a graphic summary of the living conditions that predisposed them to infection: 'soldiers, in the main, live in inordinately filthy surrounds. Their trenches are dug in ancient barnyards;

${ }^{16}$ Carrel quoted in McKellar, op. cit. (note 12), 140. Carrel was aware of the unique advantages afforded him by Rockefeller money, having written to Cushing in 1907 that, 'From a scientific standpoint, the Rockefeller Institute appears to me as an ideal place where it is possible to make successfully experiments quite impossible elsewhere', 141.

${ }^{17}$ Hannah Landecker, 'Building "A new type of body in which to grow a cell”: Tissue Culture at the Rockefeller Institute, 1910-14', in Stapleton, Creating a Tradition of Biomedical Research (2004), 151-74.

${ }^{18}$ See, for example: Alexis Carrel, 'Tissue Culture and Cell Physiology', Physiological Reviews, 4, 1 (1924), 1-20; Alexis Carrel, 'Physiological Time', Science, 74, 1929 (1931), 618-21.

${ }^{19}$ George W. Corner, A History of the Rockefeller Institute, 1901-53: Origins and Growth (New York: The Rockefeller Institute Press, 1964), 153-4; McKellar, op. cit. (note 12), 141.

${ }^{20}$ Cusimano et al, op. cit. (note 14), 1142; Ann Rothwell, 'Alexis Carrel: Innovator Extraordinaire', The Journal of Perioperative Practice, 21, 2 (2011), 73-6; P. Dutkowski, O. de Rougemont and P.A. Clavien, 'Alexis Carrel: Genius, Innovator and Ideologist', American Journal of Transplantation, 8 (2008), 1998-2003.

21 Alexis Carrel to Simon Flexner, 17 December 1914, RAC, RU, RG 450, 'Faculty/Alexis Carrel', Series C232, 'Administrative Correspondence', Box 2, Folder 1, 1906-16.

22 Ibid

23 Alexis Carrel, 'Science has perfected the Art of Killing - Why Not of Saving?', Surgery, Gynecology and Obstetrics, 20 (1915), 710-1.

${ }^{24}$ For an overview of this controversy see J.S. Haller, 'Treatment of Infected Wounds during the Great War, 1914 to 1918', Southern Medical Journal, 85 (1992), 303-15. 
their bodies are sweaty and dirty; their clothes are covered with mud. ${ }^{25}$ The result was a catastrophic rate of gas gangrene, suppuration and amputated limbs that fed the morbid iconography of the Great War and its aftermath, a grim tragedy for countless fighters, dead or dismembered, and the surgeons helpless to revive them. ${ }^{26}$ By the later months of 1914 , a 'stampede of discouragement' was pervading the ranks of military surgeons who frenzied forth 'innumerable ideas' to combat the problems of sepsis. ${ }^{27}$

Yet this was not the first time Carrel had confronted the puzzle of wounds. He had long maintained that science had failed to optimise the rate of human reparation, which he thought could be accelerated to a hitherto unimagined extent. ${ }^{28}$ In September 1909, his chance witnessing of an event at Lourdes fortified his convictions:

A few days ago, I could make two very important observations on the activation of wound healing. I went to Lourdes, and ... was allowed to observe a few patients. On a small ulceration, I saw the epithelisation occurring in a few minutes. This fact had never been exactly observed. I am more than pleased to have seen it. It demonstrates that my hypothesis of the possibility of an enormous activation of cicatrisation of tissues is not a dream. Unfortunately, I have not the faintest idea of the cause of the phenomenon. ${ }^{29}$

Carrel had started work on cicatrisation in 1907 shortly after his arrival in New York. ${ }^{30}$ By 1910 he was emboldened to make claims to readers of the Journal of the American Medical Association about the unrealised potentials of wound treatment, and make public his wish to activate and accelerate the hidden processes of human reparation: 'wounds which heal in a few days could possibly be caused to heal in a few hours.' 31 With the constant traffic of wounded soldiers, the war provided Carrel the opportunity to explore these potentials on a dramatically-increased scale, and by early 1915 he had agreed with the French Minister of War on a plan to establish a military hospital partly funded by the Rockefeller Institute. ${ }^{32} \mathrm{He}$ chose a location in the buildings of a once-fashionable hotel, the Rond Royal, on the edge of the Fôret de Compiègne just $12 \mathrm{~km}$ from the frontline. ${ }^{33}$ Boasting unique facilities, it was an ideal venue to continue research on wound infection and reparation. When Cushing paid his friend a visit in April 1915, he could not help but remark on its lavish appointment:

There are at present 51 beds with 86 attendants, including slaveys of all kinds - 11 scientific, medical, and administrative officers; 13 experienced Swiss nurses supplied by Theodor Kocher; numerous secretaries, laboratory technicians, linen-room people, scrub women, ambulance men; and 47 soldier orderlies who do everything from boots to waiting on tables and keeping up the gardens. It is indeed a research hospital de luxe. . 34

${ }^{25}$ Quoted in L.G. Walker Jr., 'Carrel's War Research Hospital at Compiègne: Prototype of a Research Facility at the Front', Journal of the American College of Surgeons, 195, 6 (2002), 870-6: 873.

${ }^{26}$ On the problem of gas gangrene, see Derek S. Linton, 'The Obscure Object of Knowledge: German Military Medicine Confronts Gas Gangrene during World War I', Bulletin of the History of Medicine, 74, 2 (2000), 291-316.

${ }^{27}$ G.A. Moore, 'The Carrel-Dakin Method of Treating Septic Wounds; Its Application to Civil Surgery', Boston Medical and Surgical Journal, 178, 4 (1918), 109-16: 109.

${ }^{28}$ Carrel, op. cit. (note 23), 710-11. On the ironies of the Great War, see Modris Eksteins, Rites of Spring: The Great War and the birth of the modern age (London: Houghton Mifflin Harcourt, 2000).

${ }^{29}$ Carrel to Flexner, 3 September 1909, RAC, RU, RG 450, Series C232, Box 2, Folder 1, emphasis in original.

${ }^{30}$ In 1908, Carrel initiated a course of experiments to examine the relations between the size of wounds and the rate of cicatrisation: Alexis Carrel and Alice Hartmann, 'Cicatrization of Wounds I. The Relation between the Size of a Wound and the Rate of its Cicatrization', The Journal of Experimental Medicine, 24, 5 (1916), 429-50.

${ }^{31}$ Alexis Carrel, 'The Treatment of Wounds', Journal of the American Medical Association, 55, 25 (1910), 2148-50: 2148 .

${ }^{32}$ Corner, op. cit. (note 19), 136; Walker, op. cit. (note 25), 870.

${ }^{33}$ Walker, op. cit. (note 25), 870.

${ }^{34}$ Harvey Cushing, From a Surgeon's Journal, 1915-8 (McClelland and Stewart, 1936), 33. 
At Compèigne, research progressed rapidly. Among Carrel's team was a talented English chemist, Henry Dakin. Carrel had determined early on to pursue an antiseptic solution to the problem of infection ${ }^{35}$ and worked closely with Dakin to find an appropriate germicide. By March 1915 he was ready 'to try a new treatment of wounds and some of Dakin's substances', which had already produced encouraging results. ${ }^{36}$ By July they had agreed on an antiseptic and had devised the method's essential components: 'The work of Dakin has given excellent results and we are about to try his substances on a larger scale in some of the first line ambulances. ${ }^{37}$

This antiseptic procedure differed from others insofar as it was founded on Carrel's earlier and ongoing experimental work on cicatrisation, and on the formulas of Pierre Lecomte du Noüy, an officer with mathematical training who, at the end of 1914, found himself in Compiègne in charge of food provisions for a division of the French army. Carrel approached Lecomte du Noüy with the problem of how to accurately determine the surface area of wounds and how to establish the geometric law of cicatrisation. In his recollections of working with Carrel, who he deemed a 'spiritual godfather', ${ }^{38}$ Lecomte du Noüy recalled how biologists working on the same problem had been 'paralysed' by their acute awareness of the multiple factors of cicatrisation: 'My ignorance of these elements freed me from the chains which fettered them [...] Dr Carrel had foreseen that a brain trained in such methods [i.e. mathematics] was better adapted to attack this problem than one inhibited by a mass of knowledge and by habits of thought. ${ }^{39}$ In 1916, a series of research papers in the Rockefeller Institute's journal, The Journal of Experimental Medicine, began outlining experiments conducted first in America then in France, which sought to unveil the hidden laws of wound reparation. It was in the first of these that Carrel made reference to the 'planimeter' - an engineering tool for determining the area of a surface in square centimetres, suggested to him by Lecomte du Noüy - as a means for establishing geometric order upon the anarchic complexity of sterile wound reparation. ${ }^{40}$ During early experiments in New York, Carrel determined that the rate of cicatrisation of a wound is greater at the start of a period of repair than at the end, and, most important, that the curve representing the contraction of an aseptic wound is regular and geometric, thus offering a standard for determining the antiseptic power of germicidal agents. ${ }^{41}$ This standard, to be expressed mathematically by Lecomte du Noüy, was vital in that it allowed Carrel both to quantify the effects of his method and to defend against sceptical attacks (see Figure 1).

Enrolling these experimental insights into the treatment of wounds, Carrel saw himself as rejuvenating the neglected wisdom of the antiseptic tradition associated with Joseph Lister. The Frenchman hoped to rehabilitate antisepsis on a rational basis, and thereby to compensate for the striking failures of aseptic, open-air and physiologic methods common at the time. Yet it was a deeply controversial position to take on - antisepsis had been

\footnotetext{
35 In this month he wrote to Flexner: 'I believe that the finding of very powerful antiseptics is of great importance.' Carrel to Flexner, 22 December 1914, RAC, RU, RG 450, Series C232, Box 2, Folder 1.

36 Alexis Carrel to Henry James, 26 March 1915, RAC, RU, RG 450, Series C232, Box 2, Folder 1.

37 Carrel to James, 1 July 1915, RAC, RU, RG 450, Series C232, Box 2, Folder 1.

38 'To Alexis Carrel the spiritual godfather of this book', the dedication of Pierre Lecomte du Noüy, Biological Time (New York: The Macmillan Company, 1937).

${ }^{39}$ Ibid., 71-2. On data collection by the unskilled, see Lorraine Daston and Peter Galison, Objectivity (Chicago:

Zone Books, 2007), 95-6.

${ }^{40}$ Lecomte du Noüy, op. cit. (note 38), 55; see also, Selcer, op. cit. (note 6), 93-6.

${ }^{41}$ Carrel and Hartmann, op. cit. (note 30), 449-50; Lecomte du Noüy, op. cit. (note 38), 57-65.
} 


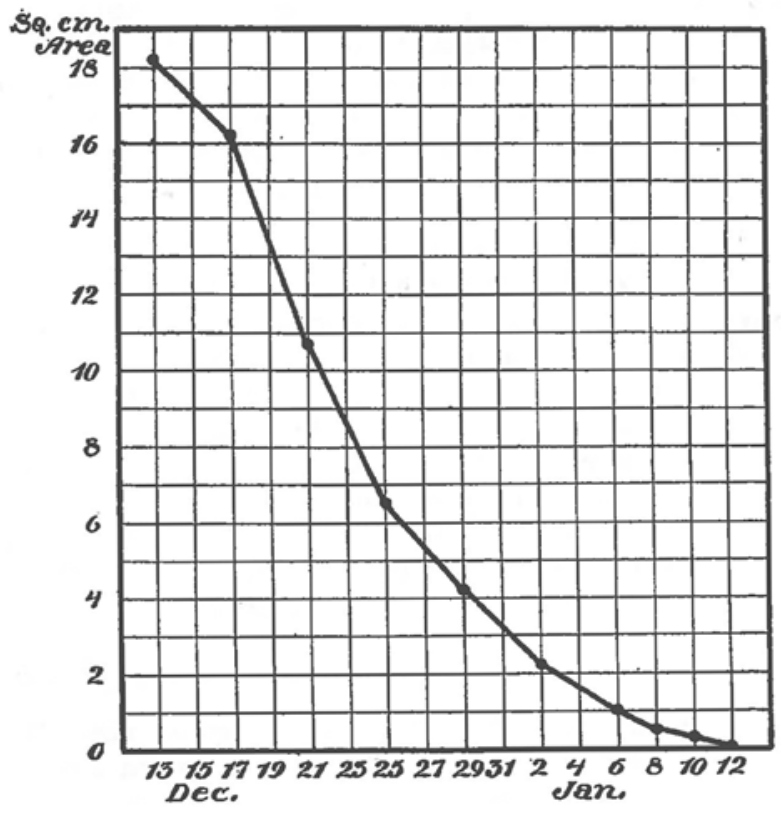

TeXr-Fig. 1.

Experiment 1.-Patient 221, age 27 years (Text-fig. 1). Old wound of the left foot; aseptic. Normal cicatrization.

$\begin{array}{llrcccccccc} & \text { Dec. 13 } & 17 & 21 & 25 & 29 & \text { Jan. 2 } & 6 & 8 & 10 & 12 \\ S \ldots \ldots \ldots & 18.2 & 16.2 & 10.7 & 6.5 & 4.2 & 2.2 & 1.0 & 0.5 & 0.3 & 0 \\ R \ldots \ldots \ldots & & 0.5 & 1.37 & 1.05 & 0.55 & 0.5 & 0.3 & 0.25 & 0.1 & 0.15 \\ S \ldots \ldots \ldots & 36.0 & 11.8 & 10.1 & 11.8 & 8.4 & 7.3 & 3.0 & 5.0 & 2.0 & \end{array}$

Figure 1: Carrel's curve for normal cicatrisation. To establish the curve, Carrel made measurements of the wound at regular four-day intervals, tracing the area onto transparent cellophane with a wax pencil. The cellophane drawings were then reproduced on a sheet of paper from which the area of the wound (S) and the area of the wound and the cicatrix ( $\mathrm{S}$ and $\mathrm{C}$ ) were estimated in square centimetres by means of the planimeter. Carrel obtained the daily rate $(\mathrm{R})$ of cicatrisation by dividing the differences of two consecutive surface estimates by the time elapsed between each observation. In this way, Carrel explained, he could ascertain the size of the wound, the size of the cicatrix, and the rate or 'velocity' of wound repair. He was further able to examine the relations between the size of a wound and the rate of cicatrisation. From Alexis Carrel and Alice Hartmann, 'Cicatrization of Wounds I. The relation between the size of a wound and the rate of its cicatrization', The Journal of Experimental Medicine, 24, 5 (1916), 429-50: 432.

troubled during the rise of asepsis, the barbarity of Lister's sterilising agents cited as justification for the pre-emptive elimination of germs ${ }^{42}$ - and in doing so Carrel stoked a storm of fierce debate about the proper approach to infection. ${ }^{43}$ Prominent and polemical opponents to antisepsis claimed that germicidal agents were simply ineffective for the sterilisation of projectile wounds, in which fragments of shell, shrapnel, manure and mud

42 Thomas Schlich, 'Asepsis and Bacteriology: A Realignment of Surgery and Laboratory Science', Medical History, 56, 3 (2012), 308-34.

${ }^{43}$ Haller, op. cit. (note 24), 303. 
lingered deeply among lacerated flesh beyond the reach of topical agents. According to the most prominent and vocal critic of antisepsis, the English pathologist Sir Almoth Wright, logic alone confirmed the futility of germicides against infection: 'the microbes are inaccessible. They have been carried down deep into the tissues, and lie on the inner face of a torn and ragged track; and that track is blocked by blood clot and hernia of muscle. ${ }^{44}$

Carrel had therefore to confront influential objections in order to demonstrate the effectiveness of his method to the wider surgical community in France, Britain, America and elsewhere. This was one reason why his experimental work on cicatrisation was so important. With scientific findings, Carrel could explain why antiseptic interventions had hitherto failed, and how with critical revisions they might succeed. ${ }^{45}$ 'The idea must be grasped', he wrote in 1917, 'that a given antiseptic substance, applied at a certain concentration, and during a certain time, is able to destroy microbes without damaging the normal tissues to any appreciable extent. ${ }^{46}$ Hence it would not be by means of 'the marvellous properties of a new drug ${ }^{47}$ that such results would follow, but from systematic experimentation with a whole range of chemical antiseptics applied at specific concentrations for precise intervals. Dakin considered around 200 in total. ${ }^{48}$ Like Carrel, the chemist insisted it was not merely bactericidal quality that counted for success in antisepsis, but a medley of factors working together. These included the penetrative power of a germicide through human tissues, its toxicity and solubility, its antiseptic power among flesh and pus, and, most important, the degree of irritation it caused to patients. ${ }^{49}$

The experimental establishment in 1915 of hypochlorite of soda as the most appropriate antiseptic was therefore an important step not only in the development of the Carrel-Dakin method, but also in the broader defence of antisepsis. ${ }^{50}$ In particular, it provided Carrel and Dakin a rejoinder to accusations of 'the fallacy of taking the figures for an antiseptic acting on microbes in watery suspension and seeing in these an all-round formula of efficacy'. ${ }^{51}$ Moreover, Carrel's experimental efforts offered him a means for countering the a priori doubts about antisepsis common to such sceptics as Sir Almoth Wright. ${ }^{52}$ To the latter's insistence that germicidal agents were incapable of penetrating deep enough into human tissues to eliminate microbial infections, Carrel produced an experimentally-based rebuttal which, based on the normal curve of the planimeter, testified to the restorative power of antiseptics under controlled conditions. Indeed, Carrel and Dakin met Wright's objection not only in their experimental identification of an appropriate antiseptic but also in their claim that the effectiveness of any antiseptic hinged on its role in a wider system of

\footnotetext{
44 Sir Almoth Wright, 'An Address on Wound Infections; and on some new methods for the study of the various factors which come into consideration in their treatment', The British Medical Journal, (1915), 720-3: 720.

45 On the uses of science for medicine beyond rhetoric, see John Harley Warner, 'The History of Science and the Sciences of Medicine', Osiris, 10 (1995), 164-93: 178; Cooter and Sturdy, op. cit. (note 5), 421-4.

46 A. Carrel and G. Dehelly, The Treatment of Infected Wounds, H. Child (trans.) (Toronto: Macmillan, 1917), 13.

47 Ibid.

48 Corner, op. cit. (note 19), 136.

${ }^{49}$ H.D. Dakin, 'On the Use of Certain Antiseptic Substances in the Treatment of Infected Wounds', The British Medical Journal (28 August 1915), 318-20.

${ }^{50} \mathrm{Ibid}$.

51 Sir Almoth Wright, op. cit. (note 44), 721.

52 Notably, Wright was not dismissive of Carrel's innovation. In 1917, he conceded to readers of The Lancet that the Carrel-Dakin treatment was by 'far the most important contribution made to surgical technique since the beginning of the war.' See Almoth Wright, 'A Lecture on the Treatment of War Wounds: Supplemented by Additional Matter Relating to Antiseptics and the Method of Carrel', The Lancet (23 June, 1917), 939-49.
} 
wound treatment. 'In the sterilisation of a wound,' Carrel and Dehelly later explained, 'the antiseptic plays a part comparable to that of the scalpel in a surgical operation. It is only an instrument, and does not constitute a method. But the choice of a good instrument is a factor indispensable to success. Chloramines and Dakin's hypochlorite are admirable instruments. 53

Having found a suitable antiseptic solution in Dakin's hypochlorite, the fundamentals of the Carrel-Dakin method - as opposed to the details of its specific instruments - could be set out in full. The procedure was outlined most lucidly in 1917 across several chapters of The Treatment of War Wounds (one of two monographs to appear that year on the subject), and included four distinct but occasionally simultaneous phases. ${ }^{54}$ The first was the careful preparation of the wound for sterilisation by the debridement or 'mechanical cleansing' of infected surface tissues, in order to enable the necessary 'intimate contact' between the antiseptic solution and invading microbes. The timing of this stage was vital. Carrel, like most military surgeons of the time, attached paramount importance to the rapid treatment of war casualties and debridement of wounds. Initial cleansing was followed by the chemical sterilisation of the second stage, the intermittent or continuous instillation of the sterilising agent across all portions of the wound by means of small rubber tubes with perforated holes at half-inch intervals (Figure 2). ${ }^{55}$ To monitor the effects of antisepsis and the progress of cicatrisation, daily clinical and bacteriological examinations were necessary (the third stage: "control' ${ }^{56}$ ), which preceded stage four, the timely closure of the wound, permissible once bacteriological smear tests failed to detect microbes for three consecutive days, coincident with improved clinical signs in the patient (a regular temperature and a good condition of the limb). ${ }^{57}$ Carrel insisted that in all cases success demanded the rigorous observation of each stage in its myriad specificity. Any diversion from the procedure would proffer negative, if not disastrous, results. ${ }^{58}$

The method produced by Alexis Carrel and his colleagues thus converged disparate spheres of expertise upon the singular problem of infected wounds. It was grounded in experimentally-produced knowledge of cicatrisation and adhered to the Listerian tradition of antisepsis. By determining the normal rate of human reparation, Carrel had developed not just a method of wound treatment but a standard upon which this and other interventions could be adjudicated. Furthermore, he was keenly aware that his scientific solution to sepsis went beyond the limbs of men into the industrial and economic heartland of nations. 'Our antiseptic treatment of wounds is very successful', he announced in November 1915: 'If it were properly applied, it would save to France many men and many millions. ${ }^{59}$

\footnotetext{
53 Carrel and Dehelly, op. cit. (note 46), 53; Henry Dakin, 'The Antiseptic Action of Hypochlorites: The Ancient History of the "New Antiseptic", The British Medical Journal, 2 (1915), 809-10.

54 The second was J. Dumas and A. Carrel, Technic of the Carrel Method (Hoeber: New York, 1917).

55 A.P. Gould et al., 'Report to the Director-General Medical Services on our Recent Visit to France to Study the Carrel-Dakin Treatment of Wounds', Journal of the Royal Army Medical Corps, 195 (2002), 870-6.

56 'The Rockefeller Institute of Medical Research War Demonstration Hospital: Report for Year 1918', 5, RAC, RU, RG 1, Series 600-2, 'The War Demonstration Hospital', Box 16, Folder 10.

57 Carrel and Dehelly, op. cit. (note 46), 89-187.

58 Ibid., 11-12, and also in correspondence, such as Carrel to James, 5 June 1916, RAC, RU, RG 450, Series C232, Box 2, Folder 1.

${ }^{59}$ Carrel to James, 1 November 1915, RAC, RU, RG 450, Series C232, Box 2, Folder 1.
} 

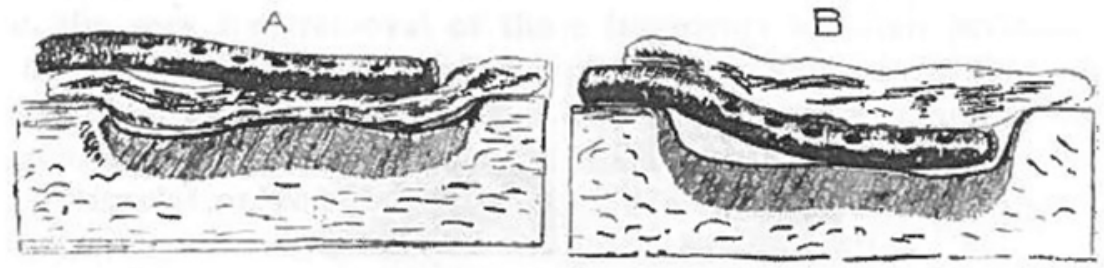

P1G. 1.-A, defective application of tube; $B$, correct application of tube.
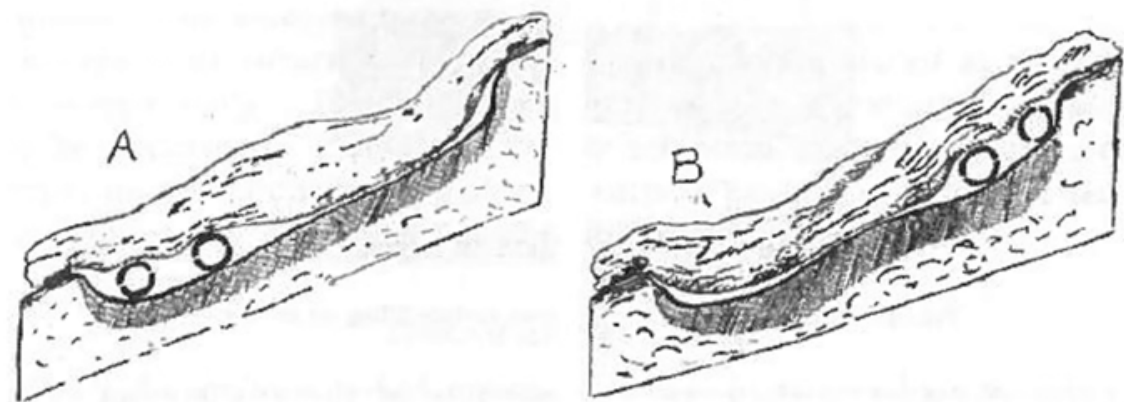

Fic. 2.-Oblique wound. A, tubes wrongly applied at bottom of wound; $B$, tubes correctly applied at top of wound.

Figure 2: There were many sources of error in following the Dakin-Carrel method of wound treatment. One of the most troublesome aspects was the correct application of irrigation tubes. The image shows correct and incorrect applications at different points in a wound. From Charles Langdon Gibson, 'The Carrel Method of Treating Wounds', Annals of Surgery, 66, 3 (1917), 262-79, 270.

\section{The Science of Wounds and the Science of Management}

Carrel viewed his intervention as thoroughly scientific. It was a mechanical and chemical method of sterilisation founded on scientific principles, and on knowledge generated scientifically (that is, quantitatively and experimentally). After its formulation in 1915, Carrel struggled with resistance from French surgeons, which he attributed to an antiscientific mindset. Fashioning himself as a true disciple of science, he confided to Flexner that, 'the French surgeons cannot realize that Dakin and myself, that is two laboratory workers, have found what they have failed to find': namely, a solution to the problem of infected and suppurating wounds. He intimated further that since science had enabled the effective application of antiseptics, it would be resistance to science that would impair the success of the Carrel-Dakin method elsewhere. Writing in the same letter on the problem of shock, he commented that 'the men in charge of the Service de Santé do not understand that important results can be obtained from scientific studies.' For Carrel, 'true progress comes only from scientific research, and not from clinical work.' 60

Even as the irony of a war in which science had 'perfected the art of killing' became clear, such unmitigated praise was not anomalous. Long before Carrel wielded scientific means against conflicts and miracles, others had already employed them in service of peacetime dilemmas. In the late nineteenth century, an engineer named Frederick Winslow Taylor began developing a system of management that became emblematic of the broader

${ }^{60}$ Carrel to Flexner, 18 March 1916, RAC, RU, RG 450, Series C232, Box 2, Folder 1. 
American 'efficiency craze' of the period. Historians have noted parallels between Taylor's project and simultaneous developments in medicine. Where sometimes this has meant redefining the term 'scientific management' to include a much broader spectrum of changes than it originally encompassed,${ }^{61}$ for Taylor and his disciples the term denoted a specific means for the (re-)organisation of labour in factories for the purpose of increased productivity at lower costs. Though not the first attempt to tackle such problems, Taylor's effort to cure the natural and systemic 'soldiering' of workers was unique in both its employment and its valuation of scientific means. His dream was the application of science to the analysis of work, his means the decomposition of work into its elementary operations, the systematic improvement of each part, and their recombination into an optimal whole. ${ }^{62}$ With the tools of science, Taylor maintained, work could be improved and improved work standardised.

To achieve these goals, Taylor's solution was not to multiply divisions of labour or to introduce technological innovations (the historian Samual Haber points out that Taylor regarded both strategies with suspicion); ${ }^{63}$ rather, he sought to improve labour by separating the conception of work from its execution, and then transferring all brainwork away from the shop floor into the hands of management. This radical and absolute division of thinking from doing resulted in the dissociation of workers from the labour process and assured the absolute control of the labour process by a centralised planning department. ${ }^{64}$ Not only were labourers excluded from conceptual work, it was crucial that they could not derive or comprehend the ideas that management controlled. ${ }^{65}$ The science of work itself was founded on a scrupulous management of the motions of each labourer. Taylor explained that his 'whole system rests upon an accurate and scientific study of unit times, which is by far the most important element in scientific management. ${ }^{66}$ Hence the stopwatch, Taylor's means for dividing an activity into its elementary operations, the best of which could be reconstituted into a newly-efficient whole. If Taylorite revolutions hinged on the concentration of brainwork away from the shop floor, it was the body of the worker that constituted the target of reform in the application of science to industry. Thus the diminishment of thought among labourers accompanied a scrupulous focus on the physicality of their work. What made this focus scientific was measurement: ${ }^{67}$ the stopwatch studies favoured by Taylor, and later the time-and-motion methods perfected by his early disciples and later antagonists, Frank and Lilian Gilbreth. ${ }^{68}$ As Anson Rabinbach

${ }^{61}$ Cooter and Sturdy, op. cit. (note 5), 423.

62 Frederick W. Taylor, Scientific Management: Comprising Shop Management, The Principles of Scientific Management, and Testimony Before the Special House Committee (New York: Harper and Brothers Publishers, 1947), 83-7.

${ }^{63}$ Haber, op. cit. (note 4), 26.

64 'All possible brain work should be removed from the shop and centered in the planning or laying-out department', Taylor, Shop Management, op. cit. (note 62), 98-9. See also: Taylor, The Principles of Scientific Management, op. cit. (note 62), 25-6; Braverman, op. cit. (note 6), 59-83; and H.S. Person, 'The contribution of scientific management to industrial problems', in Edward Eyre Hunt (ed.) Scientific Management since Taylor: A Collection of Authoritative Papers (New York: McGraw-Hill, 1924), 31-6: 32.

65 Taylor, The Principles of Scientific Management, op. cit. (note 62), 25-6; Haber, op. cit. (note 4), 24.

66 Taylor, Shop Management, op. cit. (note 62), 58.

${ }^{67}$ Hence for the Gilbreths: 'Scientific management is simply management that is based upon actual measurement', Frank B. Gilbreth and Lillian M. Gilbreth, Applied Motion Study: A Collection of Papers on the Efficient Method to Industrial Preparedness (New York: Sturgis \& Walton Company, 1917), 3.

68 The Gilbreths' methods for measuring motion are reviewed in ibid., 21-40. See also Sharon Corwin, 'Picturing Efficiency: Precisionism, Scientific Management, and the Effacement of Labor', Representations, 84, 1 (2003), $139-65$. 
remarked, according to the new doctrines of scientific management the 'rationalization of production was predicated on the rationalization of the body. ${ }^{69}$

Ways to rationalise bodies reached an apotheosis in the efforts of the Gilbreths, who, in their attempts to extend scientific management beyond the sphere of industry devised various methods to visualise, measure, anatomise and quantify the physical motions of labour. 'Motion study', which determined what path a motion was to follow, gave visual enrichment to 'time study', which determined how swiftly a path was to be traversed; time-and-motion study was an effort to identify skills and transfer them among workers. Notably, Frank Gilbreth had taken a special interest in hospital management and surgery, criticising Taylor's alleged glorification of the surgeon as the 'best mechanic', and insisting to the contrary that 'surgeons could learn more about motion study, time study, waste elimination, and scientific management from the industries than the industries could learn from the hospitals. ${ }^{70}$ Modern surgery was full of wasteful motions, he contended, and in place of its culture of haphazard guesswork imagined 'a race of superskilled' surgeons whose elementary habits of motion were to be cleaved from a genius minority. ${ }^{71}$ Here the image of skill was unambiguously joined to a critique of charisma in industry, and to the rejection of all forms of ineffable knowledge. It was a 'democratic' vision that sought to prise skills from the facets of personality and recast them as transferable quantities:

Through a comparison of the motions used in different lines of work, in the industries, in surgery and in other kinds of activity, it can be shown that the same identical motions are used in doing what are usually considered widely different types of work. This allows of an instantaneous location of the place where skill is lacking, of a tremendous amount of transference of efficient methods from one trade, craft or profession to another; and of a consequent saving in time and energy. ${ }^{72}$

Despite the novelty of the techniques, their underlying concerns were not unorthodox. By the time the Gilbreths published on the topic of surgical superskills in 1916, standardisation in surgery was being widely discussed. Finney's address had not been the first to consider it. Others had outlined more positive programs for achieving a standardised surgical practice, such as the Brooklyn gynaecologist Robert Dickinson, who, inspired by the time-and-motion studies of the Gilbreths, believed that surgery could import the insights of scientific management to great effect. ${ }^{73}$ It was the sort of external interference that Finney would attack just months later from his platform at the American Medical Association. The Gilbreths, after all, had denied any qualitative difference in unit motions across practical domains (the surgeon's motions were ultimately at one with the bricklayer's), and further maintained that the effective reform of hospital management required intervention by outsiders: '[a] concession that must be made is in the willingness to allow a man not trained either in surgery, medicine, or hospital management to apply the measurement and determine the resulting standards. ${ }^{74}$ True to this advice, Dickinson's idea was to reform the very physicality of surgery to instil the most efficient habits of motion, a resolution that captured a defining aspect of scientific management consistent

\footnotetext{
${ }^{69}$ Anson Rabinbach, The Human Motor: Energy, Fatigue, and the Origins of Modernity (University of California Press, 1990), 243.

${ }^{70}$ Frank B. Gilbreth, 'Motion Study in Surgery', Canadian Journal of Medicine and Surgery, 40, 1 (1916), 22-31: 23.

${ }^{71}$ Ibid., 31.

72 Gilbreth and Gilbreth, op. cit. (note 67), 92.

73 Robert L. Dickinson, 'Standardization of Surgery', Journal of the American Medical Association, 63, 9 (1914), 763-5; see also Morman, op. cit. (note 10), vi-viii.

${ }^{74}$ Frank B. Gilbreth, 'Scientific Management in the Hospital', The Modern Hospital, 3, 5 (1914), 321-4: 322.
} 
across its various guises: that having claimed conceptual control of the work process, an external force of management should reform workers to the new relations of production; the inherent limitations of workers, in terms of talent or intellect, placed no necessary boundaries on the possibilities of reform.

These features of scientific management have been the focus of much contemporary and historical criticism, a great portion of which has targeted the implications of Taylor's ideas for skilled work and craft-based trades. 'This process', wrote one early critic, 'separates skill and knowledge even in their narrower relationship. When it is completed, the worker is no longer a craftsman in any sense, but is an animated tool of the management. ${ }^{, 75}$ Such criticisms held equally for the Gilbreths, who in revising Taylor's ideas had become preoccupied with the question of skill transference. Although their idea of skill was ostensibly democratic, they could define a 'superskilled' operator as merely the aggregate and executor of the best elementary motions, motions which had been dissembled from the bodies of others and reconstituted afresh: 'there is some one best way for doing each thing that is done, but the complete best way is seldom in the consecutive acts of any one person', hence: 'The ultimate [best] method will be a synthesis of the best elements of all methods submitted. ${ }^{76}$ This process, the synthesis of best elements in any one person, constituted the transfer of skill. But it was a process that necessarily voided 'skill' of any conceptual requirement beyond moving habitually through the best 'elementary motions'. ${ }^{77}$ This was not, by any measure, the sort of skill lamented by critics of Taylor and his acolytes, nor would such critics likely accept a definition of craftwork as the synthetic aggregate of best elements. On the Gilbreths' thinking, skill dwelt on the surface of workers, in their waste-eliminating motions, cycles of decomposed practice captured stereoscopically and rendered transferable. A kind of regimented mimicry, it upheld Taylor's strict division of thinking and doing, suppressed creative workers and their ideas, and diminished scope for judgement, impulse, creed or whim. ${ }^{78}$

Despite disagreement among historians as to the role of scientific management in deskilling industrial work, it is yet easy to see why Carrel's standardisation of wounds has raised comparable accusations with regard to surgical practice. Although he never drew directly on Taylorite doctrines, there are striking parallels between his rehabilitation of antisepsis and the scientific reform of management. First was the shared reverence for science, the conviction that scientific methods would yield imperishable truths about best practice. The ironies of war, which Carrel noted, did not temper his zeal for scientific remedies. He defined himself as a laboratory worker and dedicated his time to research. For its lack of scientific promise he abhorred the clinic. Just like Taylor, he fused science to progress, and strove to substitute scientific solutions for subjectivity, guesswork and the 'rule of thumb'. ${ }^{79}$ Also like Taylor, he insisted on the strict observation of his method. Both men attempted to quantify chaotic realities, both to build standards on quantified grounds. Both, moreover, linked quantification to the figure of the engineer - idolised across Taylor's writings - and both intimated the artistic destinations of their respective

\footnotetext{
${ }^{75}$ Robert F. Hoxie, Scientific Management and Labor (New York: D. Appleton, 1921), 131-2; see also, Harry Braverman, op. cit. (note 6), 59-95.

${ }^{76}$ Gilbreth, op. cit. (note 74), 322-3, emphasis in original.

77 Gilbreth and Gilbreth, op. cit. (note 67), 39-40.

78 According to Frank Gilbreth, '[t]he planning must be separated from the performance'; see Gilbreth, op. cit. (note 74), 324; see also Gilbreth and Gilbreth, op. cit. (note 67), 22.

${ }^{79}$ A favoured catchphrase in Taylor's scientific management: for example, Taylor, Shop Management, op. cit. (note 62), 63 .
} 
quests, Carrel by reference to the opposed arts of killing and healing, Taylor in his utopian vision of management based on fixed principles. ${ }^{80}$

Yet as it manifested qualities of scientific management, the Carrel-Dakin method also challenged a simplistic equation of standardisation with simplicity, deskilling or the general devaluation of surgical skill. The following two sections will argue that, far from lifting it from the agenda, the attempted standardisation of the Carrel-Dakin method provoked contemporary accusations of a highly skilled technique, figuratively expanding skill as a central dynamic in surgical innovation and training.

\section{Problems of Standardisation}

By 1916, the Carrel-Dakin method had spurred widespread discussion in the medical literature of America and Europe. Convinced early on of its efficacy, Carrel hoped that the treatment he devised with Henry Dakin would be standardised throughout the French military and beyond. Yet his desires were not shared universally - especially in France, he came up against considerable resistance. By the autumn of 1915 he remarked regretfully that 'I have to spend almost all my time trying to have the doctors understand that a complete change in the results of the treatment of the wounded has already been obtained and should be obtained everywhere. ${ }^{81}$ 'The insane opposition of the French surgeons goes on', he complained the following summer. 'It is very distressing that so many young men lose their life and their limbs, when they could be saved. Their extreme conceit has [led] the French doctors to crime. ${ }^{82}$

Though Carrel was in little doubt about his major obstacle, it was not just perceived dogmatism that hampered his quest for standard practice. As discussions unfolded, commentators identified three major obstacles inhibiting the wider uptake of his technique. The first concerned the extent of its dependence on the special milieu of the forest hospital. As admirers and sceptics alike maintained, Carrel's wound treatment presupposed and demanded material resources unavailable to most military surgeons. ${ }^{83}$ On the question of whether the Carrel-Dakin method might successfully be imported to English hospitals, for instance, one cautious enthusiast remarked:

Carrel's clinic is really an experimental hospital, provided with elaborate assistance in the way of laboratory, and medical and nursing staffs. The work is carried out by those who are through long experience intimately versed in the details - a really important matter - and as keenly interested in the success of the work as is their chief. The demands made by our hospitals upon surgeons and nurses, and the limited supply, render it impossible for us to have anything approaching the personnel of the Carrel hospital. ${ }^{84}$

Rockefeller money had lavished Carrel with an elaborate workspace for surgical and physiological experimentation unavailable to most other military surgeons, and entirely unrepresentative of other wartime hospitals. These unique resources were embedded in the model of wound care he espoused - hence just as important as the institutional origins that had enabled his treatment were the material constraints it ignored. Even Sir Watson Cheyne, eminent defender of antisepsis and principal adversary of Sir Almoth Wright,

\footnotetext{
80 Ibid.

${ }^{81}$ Carrel to Flexner, 25 October 1915, RAC, Rockefeller Family, RG 2, Series 'Rockefeller Boards', Box 44, Folder 433.

82 Carrel to Flexner, 15 August 1916, RAC, RU, RG 450, Series C232, Box 2, Folder 1.

${ }^{83}$ Selcer, op. cit. (note 6), 85-92, 105.

${ }^{84}$ G. Barling, 'The Carrel Treatment of Wounds', The British Journal of Surgery, 5, 17 (1917), 116-25.
} 
doubted the extent to which Carrel's results could be replicated in most other wartime hospitals:

Carrel has the advantage which I suppose very few others have had, that he has been able to keep a patient under his own treatment for any number of days that he chooses. If on the other hand hospitals are being constantly evacuated and the patients transferred from one surgeon to another there is not continuity in the work and no method of treatment has a chance of being thoroughly tested ... [S] ome means would need to be devised by means of which the patient either is retained near the Front if badly injured or a series of teams are established of men of the same way of thinking so that the continuity of treatment is maintained. ${ }^{85}$

Thus Cheyne presented the uniqueness of the hospital as a limitation: the Carrel-Dakin method was the product of researchers uniquely funded and favourably located, but selfconsciously distant from the day-to-day realities of surgical practice.

This first obstacle to standardisation related to a second: namely, the alleged complexity of the technique. A pioneer of tissue culture, Carrel had been criticised in 1910 for his unduly complex laboratory procedures, and by mid-century had left a legacy of difficult methods and theatricality. ${ }^{86}$ From the autumn of 1917 , a similar mysticism was arising around the treatment of infected wounds by antisepsis. Admirers and critics agreed that in almost all its components, the Carrel-Dakin method was skill demanding. Even the most convinced supporters, such as the renowned American pathologist and President of the Scientific Board of the Rockefeller Institute, William Welch, could not deny that

the technic of the Carrel treatment is elaborate and requires an intelligence and skill on the part of the surgeon which cannot be counted on for the average surgeon. The preparation of the Dakin solution also requires chemical skill. There are certainly difficulties in carrying out the Carrel treatment under the condition of actual warfare, and opinions may differ as to the extent of its applicability under these conditions. . ${ }^{87}$

To this Welch added: 'Halsted has been using the Carrel method in suitable cases for a long time, for over a year, and is most enthusiastic over it, but seems to feel that not many surgeons will master it. ${ }^{88}$ The remark is noteworthy since by 1917 Halsted considered himself a most staunch supporter of the method, writing to Carrel in February that year to express his personal support: 'I doubt if anyone is more enthusiastic about it that I am. A relatively non-toxic, nonirritating antiseptic opens vistas which I have dreamed of for many years, and others of which I had not vision. ${ }^{89}$ Such remarks intimate a lingering ambivalence among the method's enthusiasts that to assert its success was simultaneously to pay homage to the unusual skill of its innovators, and therefore to doubt its wider application through wartime hospitals. ${ }^{90}$ In November 1917, a report of the Surgical Committee to the Director General of the British Army Medical Services, though ultimately recommending the adoption of the technique by the British army, noted that it 'is more elaborate than that of most wound dressing', and 'Dakin's fluid is more difficult to prepare, and its preparation has to be carried out with great precision if its proper composition is to be maintained. ${ }^{91}$ Other commentators likewise presented skill

85 Cheyne is quoted in the discussion section of William O'Neill Sherman, 'Sterilization of Wounds, Treatment of Suppurating Wounds and Osteomyelitis (Carrel Method)', Proceedings of the Royal Society of Medicine, 10 (1917), 1-28: 24.

86 Witowski, op. cit. (note 13), 279-96.

87 William H. Welch, 'The Carrel-Dakin Treatment', Journal of the American Medical Association, 69, 23 (1917), 1994.

88 Ibid.

${ }^{89}$ Quoted in Walker, op. cit. (note 25), 873.

${ }^{90}$ Cf. Selcer, op. cit. (note 6), 104.

91 'Carrel-Dakin Treatment of Wounds: Report of the Surgical Committee to the Director-General, British Army Medical Services', RAC, Rockefeller Family, RC 2, Series Rockefeller Boards, Box 44, Folder 433. 
as a thinly and unevenly distributed quality among the surgical professions of America and Europe. Carrel was among them. In the summer of 1915, as he prepared to apply his methods on a wider scale, he wrote to Henry James Jr at the Rockefeller Institute about anticipated difficulties:

The results that we obtain in our hospital are far better than those I observed elsewhere. But that may be due partly to the skill of our surgeons and nurses. I want to be sure that the treatment in an ordinary hospital is efficient. $A$ surgical method is practical only when it can succeed in the hands of unskilled and ignorant doctors. ${ }^{92}$

Carrel wrote from experience. His method for suturing blood vessels - which he put to sensational effect with the blood transfusion of a dying baby, Mary Lambert, in New York City in 1906 and which won him the Nobel Prize - had faced comparable difficulties. ${ }^{93}$ 'The operation requires delicate technic', wrote two surgeons in Chicago, 'such as is possessed only by those who have had extensive experience in blood-vessel surgery. ${ }^{94}$ Another remarked: 'Its general applicability has ... been considerably restricted owing to its difficult technic. The suture of the vessels requires a marked degree of skill, and even in the hands of men more or less experienced ... it often fails' ${ }^{95}$ The result was incremental changes to the blood transfusion procedure until it required only the most basic and well-known surgical skills, such that it could be rendered in step-by-step instructions and imitated with ease. Such changes were based on recognition that there were consequential gradations across the surgical profession. ${ }^{96}$

Such a conception of skill as unevenly distributed among American surgeons framed a specific problem of standardisation: how to make a method that could overcome the common limitations of a surgical profession. Carrel believed that besides the hospital at Compiègne, it was at only a handful of other medical facilities that 'the method is employed in its integrity. ${ }^{97}$ One common explanation for failure was the lack of appropriate surgical training in the technique. This resulted in surgeons and chemists skipping or misapprehending crucial parts of the procedure, most frequently in the preparation and application of Dakin's hypochlorite solution. The large list of possible errors (as noted by various authors), attested both to the difficulty of the method itself and to the requirement of following it exactly (see Figure 2).$^{98}$ The issue resolved into the third problem hampering the standardisation of wounds: that learning and applying the technique required direct demonstration. ${ }^{99}$ To avoid poor results, Carrel and his followers stressed the importance of dedicated firsthand experience as the only means for learning the proper application of antisepsis. So it was that on hearing from a supportive colleague, Charles Langdon Gibson, that a "very excellent surgeon who enjoyed in Paris the reputation of having mastered the technic' was obtaining poor results, Carrel had merely smiled and responded 'The gentleman stayed

92 Carrel to James, 1 July 1915, RAC, RU, RG 450, Series C232, Box 2, Folder 1, my emphasis.

93 Kara Swanson, Banking on the Body: The Market in Blood, Milk and Sperm in Modern America (Cambridge, MA: Harvard University Press, 2014), 24-30.

94 A.H. Curtis and V.C. David, 'Transfusion of Blood by a New Method, Allowing Accurate Measurement', Journal of the American Medical Association, 56, 1 (1911), 35-6: 35.

95 J.A. Hartwell, 'A Simple Method of Blood Transfusion', Journal of the American Medical Association, 52, 4 (1909), 297-8: 298.

96 Bertram Bernheim, 'Whole Blood Transfusion and Citrated Blood Transfusion', Journal of the American Medical Association, 77, 4 (1921), 275-9.

97 Carrel and Dehelly, op. cit. (note 46), 10.

98 Varied sources of common error are listed in Charles Langdon Gibson, 'The Carrel Method of Treating Wounds', Annals of Surgery, 66, 3 (1917), 262-79.

${ }^{99}$ Warwick, op. cit. (note 9), 22; Wilde and Hirst, op. cit. (note 9), 41. 
here only an hour.' ${ }^{100}$ Gibson reported that the principal operator of Carrel's hospital had been recently detached and replaced by a surgeon 'equally experienced and competent, but unfamiliar with the method [... ] Carrel told me that it took about a month for the later arrival to become familiar with the factors necessary to complete success.' ${ }^{101}$

These assumptions were reiterated in an exchange in the pages of Journal of the American Medical Association in 1917, when Arthur Dean Bevan of Chicago wrote an open letter to Welch expressing his reservations about some sensationalist reporting of the Carrel-Dakin method in portions of the popular press. Bevan maintained that the results of the antiseptic method had been strongly overstated, that its foundations were not scientific, and that further controls were needed to establish its therapeutic superiority over other methods of wound treatment. His remarks incited strong reactions. In a response published the following week, the surgeon Arthur McCormack criticised Bevan for having relied on a medley of 'letters from Joe this, and Fred that, and one operation done by Josh somebody else', and condemned Bevan's lack of experiential knowledge and his related need

to base the condemnation of a scientific method on a mere analysis of a little précis or manual which plainly states that its chief purpose is to refresh the memory of those who have participated in the course of study of the treatment under one who has had it demonstrated to him until he has mastered it. ${ }^{102}$

Despite his hostility, McCormack's response unwittingly confirmed the severe practical problems of the Carrel-Dakin method. The very fact that the technique had failed by amateurish hands of 'Joe this', 'Fred that' and 'Josh somebody else', a trio of average surgeons lacking the lavish clinics of the Rockefeller or trips to French military hospitals presided on by Nobel laureates, resonated with wider concerns about its standardisation. Further embedded in this rejoinder was a specific vision of surgical learning that ceded the epistemological paucity of textual knowledge to the priority of apprenticeship and face-to-face education. If not ineffable, surgical skills were nonetheless hard-won and would not transmit from word to hand by some mystical procedure of close reading. Instead, mastery of the method depended upon sustained observation. The 'little précis' in question, Carrel and Dehelly's Treatment of Infected Wounds, insisted as much: 'The best way to learn the method is to see it applied', it stated. 'Hence this book is especially intended to recall essential details of the technique to those who already know something of its application.' 103

\section{Means and Workers}

In the autumn of 1915, Carrel had presented surgical skill as a quality scarcely distributed among military surgeons. This conception resolved the problem of standardisation into how to make a method successful in the hands of 'unskilled and ignorant doctors'. ${ }^{104}$ His was not the normative stipulation that high skill should not play a dominant role in the progress of surgery but the descriptive estimation that it did not and indeed plausibly could not play such a role, and that the paucity of skill, conceived as a distributed quality, explained the need to work around the limits of a surgical profession. Carrel had written twice in 1916 of his desire to simplify his technique, particularly its

\footnotetext{
100 Charles Langdon Gibson, 'The Carrel Method of Treating Wounds', Annals of Surgery, 66, 3 (1917), 262-79.

101 Ibid., 263.

102 A.T. McCormack, 'A Reply by Dr A.T. McCormack', Journal of the American Medical Association, 64, 24

(1917), 2062-3: 2062.

103 Carrel and Dehelly, op. cit. (note 46), 12.

104 Carrel to James, 1 July 1915, RAC, RU, RG 450, Series C232, Box 2, Folder 1, my emphasis.
} 
chemical component. ${ }^{105}$ His preference for modification signals a first departure from the doctrines of scientific management. Rather than reforming the bodies and motions of labourers to optimise surgical performance, he approached the problem of wound care from the technical point of view: first by devising an innovation, then by simplifying its components. Where Taylor saw technology as fixed and bodies as malleable, Carrel sought to develop technologies around the fixed limits of (un)skilled bodies.

Yet despite his early intentions, the Carrel-Dakin method proved difficult to simplify. As the war went on, detractors and admirers alike maintained that the method required exceptional skill for its successful application. To this extent, Carrel had faltered in his original wish to create a technique easily adaptable to the hands of the average surgeon. Yet his mounting belief that the method should be taught face-to-face had led him to another solution to the problem of standardisation. Turning his attentions from the technique to the surgeon, he and his supporters at the Rockefeller sought to educate military and civilian practitioners in the correct principles and routines of antisepsis. This represents a second point of divergence from scientific management since teaching surgeons the technique required training them in the principles of antisepsis - it required surgeons to fully comprehend the conceptual 'brainwork' behind the procedure.

In the spring of 1917, following Carrel's insistence that the work of Compèigne was nearing an end, Simon Flexner proposed the construction of a 100-bed War Demonstration Hospital on the grounds of the Rockefeller Institute in Manhattan (see Figure 3). Designed as a movable wartime hospital, its establishment was rapid. Construction began on 1 June and staff admitted the first patient on 26 July. ${ }^{106}$ The hospital served three principle functions: to make available to civilian and military patients the Carrel-Dakin treatment; to demonstrate and teach the method to American civil and military surgeons and nurses; and to test the feasibility of a portable military hospital unit modelled on those on the Western Front. ${ }^{107}$ As well as its pedagogical and clinical features, the hospital included a large laboratory space (unlike Western Front hospitals), for research into the chemical component of the treatment. ${ }^{108}$ Instruction covered four areas in two-week courses that ran from July 1917 to March 1919: a surgical course, a chemistry course, a laboratory course and a course on special instruction. ${ }^{109}$ Over 800 surgeons attended, many of whom kept up correspondence with hospital staff to report successes and difficulties, or to enquire about the availability of equipment and solutions. After several months of teaching, Carrel concluded the following:

105 'I am trying to simplify the method and make it more active': Carrel to James, 5 June 1916, RAC, RU, RG 450, Series C232, Box 2, Folder 1. In the same folder is a letter from Carrel to Flexner, dated 15 August 1916, in which Carrel claimed that the observation that wounds can be kept sterile under chloramine and stearate, 'is a very great simplification, from a technical standpoint'.

106 'The Rockefeller Institute of Medical Research War Demonstration Hospital: Report for Year 1918', RAC, RU, RG 1, Series 600-2, Box 16, Folder 10.

107 'The Rockefeller Institute War Demonstration Hospital', The Modern Hospital, 9, 2 (August 1917), 73-80; 'The Rockefeller Institute of Medical Research War Demonstration Hospital: Report for Year 1918', RAC, RU, RG 1, Series 600-2, Box 16, Folder 10.

108 Jules Hirsch, 'The Rockefeller University Hospital (1910-2010): Creating the Science of Medicine', Perspectives in Biology and Medicine, 54, 3 (2011), 273-303. According to L.G. Walker Jr., up until its closure on 15 April 1919 the War Demonstration Hospital trained 860 doctors in the Carrel-Dakin method, treating 357 patients of whom 29 died: Walker, op. cit. (note 25), 875.

109 'The Rockefeller Institute of Medical Research War Demonstration Hospital: Report for Year 1918', RAC, RU, RG 1, Series 600-2, Box 16, Folder 10. 


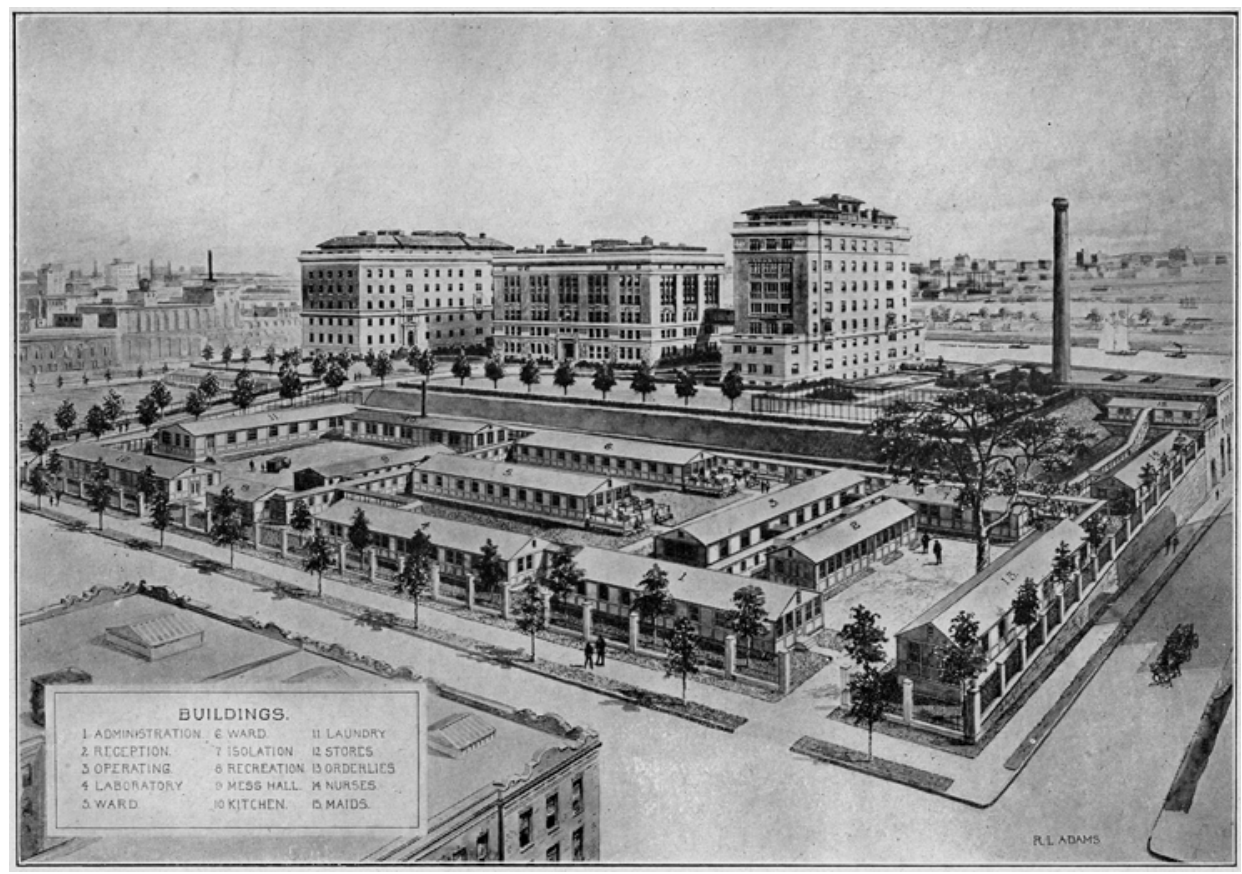

Figure 3: The War Demonstration Hospital in New York City. Picture courtesy of the Rockefeller Archive Center, Rockefeller University Collection, Record Group 1, Series 600-2 'The War Demonstration Hospital', Box 15, Folder 10.

Experience has shown that it is comparatively difficult for the average surgeon to learn these techniques, because it requires more accuracy than they are accustomed to practice. It was observed also that the training of the surgeons to use these methods has a very good influence even in their improvement in other branches of surgery, because it teaches the advantage of a precise method. ${ }^{110}$

In the Carrel-Dakin method, the science of wound care succeeded not by the rigid partitioning of thought and deed but by enjoining surgeons to partake in the correct scientific and surgical principles of antisepsis; surgeons were to be improved generally and across several domains. At the War Demonstration Hospital, confrontation with surgeons' bodies was not through the identification and control of their elementary actions but proceeded by enjoining surgeons to science, and by instilling in them the conceptual as well as the physical components of surgical precision. This positive programme for education was a foil to Carrel's earlier indictments of French surgeons as much as it was a counterpoint to the standardisation of industrial labour.

Both at Compiègne and at the War Demonstration Hospital, Carrel saw the disciples of his wound treatment as pupils of an exact method founded on scientific principles, the various stages of which demanded sound training in chemistry and detailed knowledge of such complex phenomena as wound topography and cicatrisation. His emphasis on adhesion to rules owed to his strictly holistic understanding of antiseptic action rather than to a will to transform the relations of surgery along managerial lines - it was above all

110 'What can be done for improving the present condition of war surgery', Carrel to Flexner, 14 January 1918, RAC RU, RG 450, Series C232, Box 2, 1917-22. 
the artefact of a consciously intricate antiseptic procedure combined with a dim view of a surgical profession thrust suddenly into the trials of war. The division of labour it implied was not in the spirit of divvying elements of a complex task among equivalent workers, as, say, in the production lines of Ford's great factories, but of converging disparate fields of expertise upon a single objective, and expecting the utmost of each participant. Carrel hinted at this in his explanation of why so many surgeons before him had failed in their attempts to perfect wound care: 'Experimenters have attempted, working alone, researches which needed the co-ordinated efforts of chemists, pathologists, bacteriologists, trained in scientific technique ... Despite the academic toil of many surgeons, wounds suppurate to-day as freely as ever. ${ }^{\text {,11 }}$ Science, if it was to be successful, must be collaborative. The solution to infected wounds was therefore to expand the therapeutic procedure across multiple domains of expert knowledge. Only jointly could the precision of the chemist, the dexterity of the surgeon and the fastidious care of the nurse guarantee the remarkable healing phenomena reported at Compiègne. In the Carrel-Dakin method, each role summoned the full force of its bearer, and each certainly demanded no less than the traditional cicatrisation of wounds by nature in which the surgeon alone had struggled, and only then as passive witness to the caprice of fate.

The hospital at Compiègne came under attack and was evacuated on 21 March 1918. It was destroyed completely the following day. The Great War ended on 11 November and Carrel was discharged from the French army in January the following year, after which he resumed work at the Rockefeller Institute. ${ }^{112}$ With the destruction of the hospital and cessation of hostilities, the Carrel-Dakin method began to lose its practical relevance as medical priorities shifted and surgeons turned upon new problems. For all the emphasis on Carrel's method during conflict, it was Dakin's hypochlorite that survived as an innovation in antisepsis. As Carrel implicitly foresaw, his irrigation technique was not amenable to most surgeons. His original image of skill prevailed, confining his method first to a minority and then to obscurity.

\section{Conclusion}

In his study of how the treatment of wounds by the Carrel-Dakin method became standardised during the Great War, the historian Perrin Selcer has argued convincingly that the story of the ill-fated technique exemplifies the political dynamics of standardisation, how it acts to 'reconfigure and formalize power relations in medical practice.' ${ }^{113}$ This paper has contended that a conception of surgical skill was central to those processes. It has argued further that the relationship of standardisation to skill does not appear through history as an inverse tendency. According to contemporary observers, the CarrelDakin wound treatment (and the divisions of labour it implied) demanded rather than diminished the requirement for exemplary surgical, chemical and diagnostic skills. Such commentators presented Carrel as fatally disconnected from the common realities of wartime surgery. This was the innovation of a man removed from his peers in terms of both personal and material resources. The division of labour in the Carrel-Dakin method was reflective of this unique positioning. It represented not the simplification of a method

111 Carrel and Dehelly, op. cit. (note 46), 3.

112 Walker, op. cit. (note 25), 874-5.

113 Selcer, op. cit. (note 6), 105. 
by way of dividing its elements among equals but the coordination of disparate experts around the shared dream of antiseptic control.

As such, attempts at standardisation did not dissolve debates about the status of skill in surgery, rather, they entered and complicated those debates, and compelled disputants into conceptual struggles over the nature of skill as an embodied but scarce quality. From late 1914, the Carrel-Dakin method was bound to a figurative expansion of surgical skill: how a technique of wound antisepsis was to be shared uniformly and universally prompted various engagements about the idea of skill relative to surgical practice. Carrel's early view, resonant with the later remarks of Welch, Halsted and others, was that surgical skill was thinly distributed among surgeons ill-prepared for the horrors of war. Despite his reverence for science, and despite his intentions to employ its procedures against infection, Carrel's dismal estimation that a sloppy surgical workforce posed intractable barriers to the treatment of infected wounds jarred markedly with the distinctive core optimism of Taylor's scientific management, which denied that the (in)competence of labour placed fixed limits on production in abundance. ${ }^{114}$ Skill as a fixed limitation was a consequential idea: it delimited the innovation, promotion and standardisation of an antiseptic wound treatment. Failing in his efforts to simplify the technique, Carrel insisted on sustained direct demonstration. When finally he confronted the surgical body in the War Demonstration Hospital, it was not to dissect, optimise and standardise its elementary motions. Rather, with the aim of intellectual expansion, Carrel preached the foundational scientific tenets at the heart of his technique. It was the broader condition of mind rather than the elementary motions of a body that mattered for the propagation of antiseptic wound treatment. As surgeons debated the efficacy and practicability of a controversial idea - whether or not it counted truly as a moment of scientific medicine, and to what extent its elaborate demands on surgeons hindered its wider application - they espoused ideals of skill fundamentally at odds with those connected to scientific management. Hence skill came to the forefront both as a practical and a conceptual issue in the standardisation of wound treatment, enlivening questions about pedagogy and science in medicine, and steering the shape and fate of a surgical innovation.

${ }^{114}$ Charles S. Maier, 'Between Taylorism and Technocracy: European Ideologies and the Vision of Industrial Productivity in the 1920s', Journal of Contemporary History, (1970), 27-61: 47. 